\title{
HARVARD MEDICAL ALUMNI BULLETIN
}

\author{
Vol. 39 No. 2
}

\section{"A Communiqué on Communication"}

It is not known how many billions of words are written in one ycar. on every conccivahle sub. ject, hut it is known that effective international communication-whether spoken or written-is both an important and difficult problem to solve. With the recent publication of the International Journal of Pychiatry it appears that "man's painful desire to communicate without coalescing" - has been accomplished. In several unusual respects the Journal is truly international. It will be published quarterly by the International Press Inc., Boston, Niassachusetts; it is edited by Jason Aronson, M.D., instructor in psychiatry and assistant psychiatrist at the Massichusetts General Hospital; and it has a list of contributors who come from all over the world.

The Journal has been designed to facilitate world-wide psychiatric communication. '1 he motivation to undertake this complex experiment has evolved from an awarencss among physicians everywhere that the cold war between liast and West and the mutual fear of devastation, is the In:ijor crisis of modern civilization. 'The concept of the Journal arose from conversitions Dr. Aronson had had with psychiatrists and sociologists in Warsaw and Noscow in 1961, while he was conducting a study of Søvict psichiatry sponsored by the U. S. Public Health Service. When he returned to this country he received great encouragement here as well, and am organizing committce was established to give advice on the problems ahead and select members of the editorial board. There are two American board members, Dr. Jack R. Ewalt, Bullard Professor of Psychiatry and head of the department of psychiatry at the Massachusetts Mental Health Center; and Dr. David Hamburg, head of the De. partment of psychiatry, Stanford I niversity School of Medicine, California. The other 11 members come from: Canada, Chile, England, Irance. India, Japan, Norway, Nigeria, Scotland and Switzerland. There is also a group of 20 physicians who act as consulting editors; these include: Drs. Frank R. Ervin, assistant professor of psvchiatry at the Massachusetts General IIospitil, Peter H. Knapp' '41, John C. Nemiah ' $43 B$, assistant professor and tutor in psichiatry and Gardner C. Quarton '44, associate in psychiatry at the Massachusetts General Hospital.

The Journal aims to cross both international and interdisciplinary boundaries through a unique format. The articles were chosen by the editoral board from 214 journals of psychiatry and hundreds of other journals in relevant fields. Each article has several commentaries by specialists from different countries, and a summary which has been translated into French, German, Spanish, Polish and Russian.

Also in the first issue appeared a controversial review on "The Effects of Psychotherapy." by $H$. J. Eysenck of England. He concluded that "the therapeutic effects of psychotherapy are small and do not in any demonstrable way add to the nonspecific effects of routine medical treatment . . ." There were 14 "discussions" of the review by psychiatrists from various countries. Some agrecing (Wolpe: "Its arguments are mainly unanswerable and its major conclusions unimpeachable."). some disagreeing (Strupp: "I fail to sce that he

gives any conclusive answers."), but each "discussion" made its contribution by clarifying some of the issues involved.

Meaning $u$ ul communication, however, is more difficult to achieve than it wonld appear to he at first glauce becaluse, different cultures apply a differcut connation to the same word. I)r. tronson rave an interesting example of this: I. M. Morosov concluded in his review of the American IIandliook of Psychiatry, that it was "pragmatic", an opinion which does not appcar to be very critical. However, in the Entsililo. pedicheskii Slowar (Encyclopedia of Words, Moscow, 195.1), pragmatism is defined as, "a reactionary, subjectively-idealistic current in modern burgeoise philosophy (that) directly rejects scientific knowledge."

In its first issue, the Journul has presented interesting matcrial in a clear. simple and professional mamner. (ne wishes that its aims may be achieved just as shillfulls.

You may subscribe at the Special HALF PRICE *

Associate rate

. . a quanterly in English with

Russian, French, German, Spanish, and l'olish summaries. Fach issue romlaims arlicles and crilical revieres selected as among llie most significant from the arorld literature.

* Regular Institutional Subscription Rate... \$20.00 Special Rate to Associates.........\$10.00

MAIL TO: International Journal of Psychiatry 32 Fruit Street, Box 462 Boston, Mass. 02114

NAME

ADDRESS:

CITY:

STATE:

Institutional Sub. scription $\$ 20.00$

Enroll me as an As. sociate and enter my subscription at $\$ 10.00$.

(Valid only on subscriptions paid for by the subscriber for his personal use)

Enclose Remittance with Order
For my convenience please make this a stand. ing order and ship future $\checkmark$ olumes automatically until the subscription is canceled.

Yes $\square \mathrm{Na}$ 